\title{
In vitro Efficacy of Bioagents and Fungicides on the Management of Dry Root Rot of Cluster Bean (Macrophomina phaseolina)
}

\author{
Ranvijay, Prashant Mishra, Abhishek Kumar* and Shashank Mishra \\ Department of Plant Pathology SVPUA\&T, Meerut- 250110, UP, India \\ *Corresponding author
}

\begin{abstract}
A B S T R A C T
The cluster bean (Cyamopsis tetragonoloba L.Taub.) also known as Guar is one of the most important commercial crop and major source of guar gum. The clusterbean is affected by various fungal diseases. Among those dry root rot caused by Macrophomina phaseolina (Tassi) Goid., a soil borne, cosmopolitan fungus infecting cluster bean and more than 500 plant species. The first symptom of disease is yellowing of the leaves, dark lesion may be seen on the bark at the ground level, the basal stem \& main root may show dry rot symptoms. The antagonistic activity of five bioagents was evaluated against $M$. phaseolina in vitro and the maximum mycelial growth inhibition of $M$. phaseolina was recorded by Chaetomium globosum (68.14\%), followed by Bacillus subtilis (67.03\%), while least mycelial growth inhibition was recorded in P. florescence (14.81\%). The inhibitory effect of eight fungicides was also tested at 100, 200 and 300ppm concentration by poison food technique, after 24 hrs of inoculation the complete inhibition of mycelial growth was found with all fungicides at all three concentration. The seven fungicides Mancozeb, Carbendazim, Saaf, Topsin-M, Tebuconazole, Hexaconazole and Propiconazole completely inhibited the mycelial growth of pathogen at 200 and 300ppm concentration.
\end{abstract}

\section{Introduction}

Pulses are major source of supplementary protein to daily vegetarian diet, these are regarded as poor man's meat. They provide energy, essential minerals and vitamins. Pulses are major source of plant protein and carbohydrates. Other nutrients like Phosphorus, Minerals, Vitamin C, Riboflavin and essential Amino acids are also major constituent. Pulses contain more calcium and iron than cereals. They contain 22-24\% protein, which is almost twice the protein in wheat and thrice that of rice. Pulses provide significant nutritional and health benefits, and are known to reduce several noncommunicable diseases such as colon cancer and cardiovascular diseases (Yude et al, 1993; Jukanti et al., 2012).

India is the largest producer, consumer and importer of pulses in the world. In India Chickpea covers 90, Pigeon pea 65 and lentil 37 percent area with production of 93, 68 and 
32 percent respectively worldwide. Among various pulse crops, chickpea dominates with over 40 percent share of total pulse production followed by pigeonpea (18-20\%), mungbean (11\%), urdbean (10-12\%), lentil (8-9\%) and other legumes (20\%) and Clusterbean is growing as minor crop (IIPR Vision 2030). Though India is the world's largest producer of pulses, it imports a large amount of pulses to meet the growing domestic needs.

It is grown principally in north-western India, Pakistan, Texas, Australia and Africa. About $80 \%$ of world production occurs in India and Pakistan, Dry Areas in Rajasthan, Gujarat, Kutch region occupies the largest area $(82.1 \%)$. Only $10 \%$ of the total production stays in country and the remaining $90 \%$ is exported for shale gas and oil industries.

A variety of stresses affect cluster bean production from planting to storage. Among these diseases are the major stresses. Different diseases hamper cluster bean production. These include viral, bacterial, fungal and nematode diseases. The majority of diseases are caused by fungi and several of them caused reduction in yield varying in different regions and seasons. Among these, soil borne fungal pathogens causing serious losses have prime importance. Due to these above diseases not only the production of Guar is hampered but its quality is also deteriorated affecting our national income.

The Clusterbean and other legumes in India often suffer from various type of root rot \& wilt. Among these the dry root rot caused by Macrophomina phaseolina (Tassi) Goid. Macrophomina phaseolina is a soil borne fungus causing the root rot disease on clusterbean and more than 500 plant species from more than 100 families (Mihail, 1992; Wyllie, 1988) distributed worldwide and is one of the cosmopolitan fungi.
The first symptom of disease is yellowing of the leaves which droop in next 2 or 3 days and withers off.

The plant may wilt within a week after the appearance of first symptom. When stem is examined closely, dark lesion may be seen on the bark at the ground level. If the plants are pulled from soil the basal stem \& main root may show dry rot symptoms, the tissues are weakened and break off easily in advanced cases sclerotial bodies may be seen scattered on the affected tissues. It produces numerous sclerotial bodies on host tissue, which measure about $110-130-\mu$ in diameter. Often the conidial or pycnidial stage is produced on the host.

\section{Material and Methods}

\section{Isolation and purification of the pathogen}

Isolation of the fungus was made by following standard tissue isolation technique. Affected plant parts were thoroughly washed in sterilized water for removing the dust and other surface contaminants. A small portion of diseased parts (stem/branch), just touching the healthy green portion, were cut into small pieces with sterilized scalpel, and then surface sterilized with 0.1 per cent mercuric chloride solution for 30 seconds.

After that pieces were washed thoroughly with three changes in sterilized, distilled water, to remove traces of mercuric chloride if any and then aseptically transferred to sterilized blotter paper to remove excess moisture and then transferred to Petri plates having potato dextrose agar medium. Then these plates were incubated at $27 \pm 1^{0} \mathrm{C}$ for 72 hours. The fungal growth, which arose through the infected tissue, was aseptically transferred to the PDA slants and in Petri plates. Pure culture of pathogen will be used for further study in vitro condition. 


\section{Management of the pathogen in vitro}

\section{$A$. In vitro evaluation of bio-agents against M. phaseolina}

The antagonistic activity of five antagonists viz. Trichoderma sp., Chaetomium sp., Bacillus subtilis and Pseudomonas fluorescence will be tested against the pathogen in vitro for their efficacy to inhibit the growth of the pathogen to a maximum extent in dual culture technique. Potato dextrose agar (PDA) will be prepared and 100 $\mathrm{ml}$ of the media will be taken in each $250 \mathrm{ml}$ flasks and sterilized. Then $20 \mathrm{ml}$ molten PDA was poured in each petriplate and kept until solidify. Effect on the growth of Macrophomina phaseolina will be studied by inoculating the pathogen at one side of the petriplates and antagonist at exactly opposite side of the same plate by leaving about $4 \mathrm{~cm}$ gap, in a petridish $5 \mathrm{~mm}$ circular bits from freshly growing pathogen and antagonist culture taken and will placed at both the peripheral ends, in case of bacterial antagonist, the bacterial culture was streaked at the periphery of the petriplate with the help of an inoculation loop. For this, actively growing cultures were used and three replications were maintained for each treatment. After 168 hours of incubation, when the growth in control plate recorded 90 $\mathrm{mm}$ in diameter, the radial growth of the pathogen was measured. The per cent inhibition of the growth over control was calculated by following the equation given by Vincent (1927).

$\mathrm{I}=\frac{c-T}{c} X 100$

Where,

$\mathrm{I}=$ Per cent inhibition

$\mathrm{C}=$ Growth in control

$\mathrm{T}=$ Growth in treatment

\section{B. In vitro evaluation of fungicides against M. phaseolina}

The effect of eight fungicides belonging to different groups (Table 1) was tested at 100ppm, 200ppm, and 300ppm concentrations in vitro for their efficacy to inhibit the growth of the pathogen to a maximum extent. Effect on the growth of $M$. phaseolina was studied using poisoned food technique (Nene and Thapliyal, 1982).

Potato dextrose agar (PDA) was prepared and $100 \mathrm{ml}$ of the medium was taken in $250 \mathrm{ml}$ flasks and sterilized. To the molten cooled sterile medium requisite quantity of the fungicides were added separately and thoroughly mixed so as to get the required concentrations for each of the fungicide. Twenty $\mathrm{ml}$ of poisoned medium was poured in to each of the $90 \mathrm{~mm}$ sterilized petriplates. Each plate was inoculated with five $\mathrm{mm}$ disc of mycelium at the center and incubated at $27 \pm 1^{0} \mathrm{C}$. Three replications were maintained for each treatment. Potato dextrose agar medium without any of the fungicide served as control. And plates were incubated at $27 \pm$ $1^{0} \mathrm{C}$ till the growth of the colony touched the periphery in control plate. The per cent inhibition of the growth over control was calculated by above formula.

\section{Results and Discussion}

\section{Evaluation of different bioagents against M. phaseolina}

The antagonistic activity of different bioagents viz. Trichoderma viride, $T$. harzianum, Chaetomium globosum, Bacillus subtilis and Pseudomonas florescence was in vitro evaluated against dry root rot pathogen $M$. phaseolina by using dual culture experiment on PDA medium, the inhibition of radial growth of pathogen was recorded against bioagents. A clear inhibition zone was 
observed between M. phaseolina and $T$. harzianum and Chaetomium globosum. The inhibition of mycelial growth of pathogen by bioagents was recorded after 24, 96 and 168 hrs.

The results from the table 2 revealed that, there was significant mycelial growth inhibition of $M$. phaseolina by all the tested bioagents. The maximum mycelial growth inhibition of $M$. phaseolina was recorded by Chaetomium globosum (68.14\%) which was significantly superior from all the tested bioagents, followed by Bacillus subtilis (67.03\%), Trichoderma harzianum (63.70\%), and Trichoderma viride caused $44.07 \%$ mycelial inhibition while the minimum inhibition per cent of mycelial growth was recorded in $P$. florescence (14.81\%). All the tested bioagents were statistically significant over control to inhibit the mycelial growth of pathogen. The result obtained have been presented in Table-2 \& illustrated in Plate-1.

Table.1 List of fungicides used

\begin{tabular}{|c|c|c|c|}
\hline Sl. No. & Treatment & Chemical name & Concentrations \\
\hline 1 & $\mathbf{T}_{1}$ & $\begin{array}{l}\text { Mancozeb 63\% WP (Dithane M- } \\
45 \text { ) }\end{array}$ & 100,200 and $300 \mathrm{ppm}$ \\
\hline 2 & $\mathbf{T}_{2}$ & Bavistin 75\% WP (Carbendazim) & 100,200 and $300 \mathrm{ppm}$ \\
\hline 3 & $\mathbf{T}_{3}$ & $\begin{array}{l}\text { Carbendazim } 12 \%+\text { Mancozeb } \\
63 \% \text { WP (Saaf) }\end{array}$ & 100,200 and $300 \mathrm{ppm}$ \\
\hline 4 & $\mathbf{T}_{4}$ & $\begin{array}{l}\text { Thiophanate-Methyl } 70 \% \quad \text { WP } \\
\text { (Topsin-M) }\end{array}$ & 100,200 and $300 \mathrm{ppm}$ \\
\hline 5 & $\mathbf{T}_{5}$ & Tebuconazole 25.9\% EC(Torque) & 100,200 and $300 \mathrm{ppm}$ \\
\hline 6 & $T_{6}$ & Hexaconazole 5\% SC (Trigger) & 100,200 and $300 \mathrm{ppm}$ \\
\hline 7 & $\mathbf{T}_{7}$ & Propiconazole 25 EC (Tilt) & 100,200 and $300 \mathrm{ppm}$ \\
\hline 8 & $\mathbf{T}_{8}$ & Chlorothalonil 75\% WP (Daconil) & 100,200 and $300 \mathrm{ppm}$ \\
\hline
\end{tabular}

Table.2 In vitro evaluation of different bioagents against M. phaseolina

\begin{tabular}{|c|c|c|c|c|c|c|c|}
\hline \multirow[t]{2}{*}{ Treatment } & \multirow[t]{2}{*}{ Bioagents } & \multicolumn{2}{|l|}{24 Hour } & \multicolumn{2}{|l|}{96 Hour } & \multicolumn{2}{|c|}{168 Hour } \\
\hline & & Average & $\%$ inhibition & Average & $\%$ inhibition & Average & $\%$ inhibition \\
\hline $\mathbf{T}_{1}$ & T. harzianum & 7 & 24.97 & 20.33 & 39 & 32.67 & 63.7 \\
\hline $\mathbf{T}_{2}$ & T. viride & 7.67 & 17.79 & 25.33 & 24 & 50.33 & 44.07 \\
\hline $\mathbf{T}_{3}$ & $\begin{array}{l}\text { Chaetomium } \\
\text { globosum }\end{array}$ & 6.33 & 32.15 & 23 & 30.99 & 28.67 & 68.14 \\
\hline $\mathbf{T}_{4}$ & $\begin{array}{l}\text { Bacillus } \\
\text { subtilis }\end{array}$ & 7.67 & 17.79 & 24.33 & 27 & 29.67 & 67.03 \\
\hline $\mathbf{T}_{\mathbf{5}}$ & $\begin{array}{l}\text { Pseudomonas } \\
\text { fluorescence }\end{array}$ & 7.67 & 17.79 & 24.67 & 25.98 & 76.67 & 14.81 \\
\hline$T_{6}$ & Control & 9.33 & 0 & 33.33 & 0 & 90 & 0 \\
\hline CD at 5\% & & N.S. & - & 3.086 & - & 2.613 & - \\
\hline SE (m) & & 0.509 & - & 0.991 & - & 0.839 & - \\
\hline
\end{tabular}


Table.3 In vitro evaluation of different fungicides at 100ppm

\begin{tabular}{|c|l|c|c|c|c|c|c|}
\hline Treatments & fungicides & \multicolumn{2}{|c|}{$\begin{array}{c}\text { Inhibition after 24 } \\
\text { hrs }\end{array}$} & \multicolumn{2}{|c|}{$\begin{array}{c}\text { Inhibition after 96 } \\
\text { hrs }\end{array}$} & \multicolumn{2}{|l|}{$\begin{array}{c}\text { Inhibition after 168 } \\
\text { hrs }\end{array}$} \\
\cline { 3 - 8 } & & $\begin{array}{c}\text { Radial } \\
\text { growth }\end{array}$ & $\begin{array}{c}\text { Percent } \\
\text { Inhibition }\end{array}$ & $\begin{array}{c}\text { Radial } \\
\text { growth }\end{array}$ & $\begin{array}{c}\text { Percent } \\
\text { Inhibition }\end{array}$ & $\begin{array}{c}\text { Radial } \\
\text { growth }\end{array}$ & $\begin{array}{c}\text { Percent } \\
\text { Inhibition }\end{array}$ \\
\hline $\mathbf{T}_{\mathbf{1}}$ & Mancozeb & 0.00 & 100.00 & 11.33 & 77.78 & 28.33 & 68.52 \\
\hline $\mathbf{T}_{\mathbf{2}}$ & Carbendazim & 0.00 & 100.00 & 0.00 & 100.00 & 0.00 & 100 \\
\hline $\mathbf{T}_{\mathbf{3}}$ & Saaf & 0.00 & 100.00 & 4.33 & 91.50 & 14.33 & 84.07 \\
\hline $\mathbf{T}_{\mathbf{4}}$ & Topsin-M & 0.00 & 100.00 & 1.67 & 96.72 & 10.00 & 88.88 \\
\hline $\mathbf{T}_{\mathbf{5}}$ & Tebuconazole & 0.00 & 100.00 & 0.00 & 100.00 & 0.00 & 100 \\
\hline $\mathbf{T}_{\mathbf{6}}$ & Hexaconazole & 0.00 & 100.00 & 0.00 & 100.00 & 0.00 & 100 \\
\hline $\mathbf{T}_{\mathbf{7}}$ & Propiconazole & 0.00 & 100.00 & 0.00 & 100.00 & 0.00 & 100 \\
\hline $\mathbf{T}_{\mathbf{8}}$ & Chlorothalonil & 0.00 & 100.00 & 20.33 & 60.13 & 49.00 & 45.55 \\
\hline $\mathbf{T}_{\mathbf{9}}$ & Control & 10.00 & 0.00 & 51.00 & 0.00 & 90.00 & 0 \\
\hline $\mathbf{C D}$ at 5\% & & & 0.576 & & 0.880 & & \\
\hline SE(m) & & \multicolumn{2}{|c|}{0.192} & & 0.294 & & \\
\hline
\end{tabular}

Table.4 In vitro evaluation of different fungicides at 200ppm

\begin{tabular}{|c|c|c|c|c|c|c|c|}
\hline \multirow[t]{2}{*}{ Treatments } & \multirow[t]{2}{*}{ Fungicides } & \multicolumn{2}{|c|}{$\begin{array}{c}\text { Inhibition after } 24 \\
\text { hrs }\end{array}$} & \multicolumn{2}{|c|}{$\begin{array}{c}\text { Inhibition after } 96 \\
\text { hrs }\end{array}$} & \multicolumn{2}{|c|}{$\begin{array}{c}\text { Inhibition after } \\
168 \mathrm{hrs}\end{array}$} \\
\hline & & $\begin{array}{l}\text { Radial } \\
\text { growth }\end{array}$ & $\begin{array}{c}\text { Percent } \\
\text { Inhibition }\end{array}$ & $\begin{array}{l}\text { Radial } \\
\text { growth }\end{array}$ & $\begin{array}{c}\text { Percent } \\
\text { Inhibition }\end{array}$ & $\begin{array}{l}\text { Radial } \\
\text { growth }\end{array}$ & $\begin{array}{c}\text { Percent } \\
\text { Inhibition }\end{array}$ \\
\hline $\mathbf{T}_{1}$ & Mancozeb & 0.00 & 100.00 & 0.00 & 100.00 & 0.00 & 100 \\
\hline $\mathbf{T}_{2}$ & Carbendazim & 0.00 & 100.00 & 0.00 & 100.00 & 0.00 & 100 \\
\hline $\mathbf{T}_{3}$ & Saaf & 0.00 & 100.00 & 0.00 & 100.00 & 0.00 & 100 \\
\hline $\mathbf{T}_{4}$ & Topsin-M & 0.00 & 100.00 & 0.00 & 100.00 & 0.00 & 100 \\
\hline $\mathbf{T}_{5}$ & Tebuconazole & 0.00 & 100.00 & 0.00 & 100.00 & 0.00 & 100 \\
\hline $\mathbf{T}_{6}$ & Hexaconazole & 0.00 & 100.00 & 0.00 & 100.00 & 0.00 & 100 \\
\hline $\mathbf{T}_{7}$ & Propiconazole & 0.00 & 100.00 & 0.00 & 100.00 & 0.00 & 100 \\
\hline $\mathbf{T}_{8}$ & Chlorothalonil & 0.00 & 100.00 & 15.33 & 70.13 & 36.33 & 59.63 \\
\hline $\mathbf{T}_{9}$ & Control & 11.00 & 0.00 & 51.33 & 0.00 & 90.00 & 0 \\
\hline \multicolumn{2}{|l|}{ CD at $5 \%$} & \multicolumn{2}{|c|}{0.998} & \multicolumn{2}{|c|}{0.744} & \multicolumn{2}{|c|}{0.632} \\
\hline \multicolumn{2}{|l|}{ SE(m) } & \multicolumn{2}{|c|}{0.333} & \multicolumn{2}{|c|}{0.248} & \multicolumn{2}{|c|}{0.207} \\
\hline
\end{tabular}


Table.5 In vitro evaluation of different fungicides at 300ppm

\begin{tabular}{|c|c|c|c|c|c|c|c|}
\hline \multirow[t]{2}{*}{ Treatments } & \multirow[t]{2}{*}{ fungicides } & \multicolumn{2}{|c|}{$\begin{array}{c}\text { Inhibition after } 24 \\
\text { hrs }\end{array}$} & \multicolumn{2}{|c|}{$\begin{array}{c}\text { Inhibition after } 96 \\
\text { hrs }\end{array}$} & \multicolumn{2}{|c|}{$\begin{array}{c}\text { Inhibition after } \\
168 \mathrm{hrs}\end{array}$} \\
\hline & & $\begin{array}{l}\text { Radial } \\
\text { growth }\end{array}$ & $\begin{array}{c}\% \\
\text { Inhibition }\end{array}$ & $\begin{array}{l}\text { Radial } \\
\text { growth }\end{array}$ & $\begin{array}{c}\% \\
\text { Inhibition }\end{array}$ & $\begin{array}{l}\text { Radial } \\
\text { growth }\end{array}$ & $\begin{array}{c}\% \\
\text { Inhibition }\end{array}$ \\
\hline $\mathbf{T}_{1}$ & Mancozeb & 0.00 & 100.00 & 0.00 & 100.00 & 0.00 & 100 \\
\hline $\mathbf{T}_{2}$ & Carbendazim & 0.00 & 100.00 & 0.00 & 100.00 & 0.00 & 100 \\
\hline $\mathbf{T}_{\mathbf{3}}$ & Saaf & 0.00 & 100.00 & 0.00 & 100.00 & 0.00 & 100 \\
\hline $\mathbf{T}_{4}$ & Topsin-M & 0.00 & 100.00 & 0.00 & 100.00 & 0.00 & 100 \\
\hline $\mathbf{T}_{5}$ & Tebuconazole & 0.00 & 100.00 & 0.00 & 100.00 & 0.00 & 100 \\
\hline $\mathbf{T}_{6}$ & Hexaconazole & 0.00 & 100.00 & 0.00 & 100.00 & 0.00 & 100 \\
\hline $\mathbf{T}_{7}$ & Propiconazole & 0.00 & 100.00 & 0.00 & 100.00 & 0.00 & 100 \\
\hline $\mathbf{T}_{8}$ & Chlorothalonil & 0.00 & 100.00 & 11.67 & 77.55 & 26.33 & 70.74 \\
\hline $\mathbf{T}_{9}$ & Control & 10.67 & 0.00 & 52.00 & 0.00 & 90.00 & 0 \\
\hline \multicolumn{2}{|l|}{ CD at $5 \%$} & \multicolumn{2}{|c|}{0.880} & \multicolumn{2}{|c|}{0.880} & \multicolumn{2}{|c|}{0.880} \\
\hline \multicolumn{2}{|l|}{ SE(m) } & \multicolumn{2}{|c|}{0.294} & \multicolumn{2}{|c|}{0.294} & \multicolumn{2}{|c|}{0.294} \\
\hline
\end{tabular}

Figure.1 In vitro evaluation of different bioagents against $M$. phaseolina

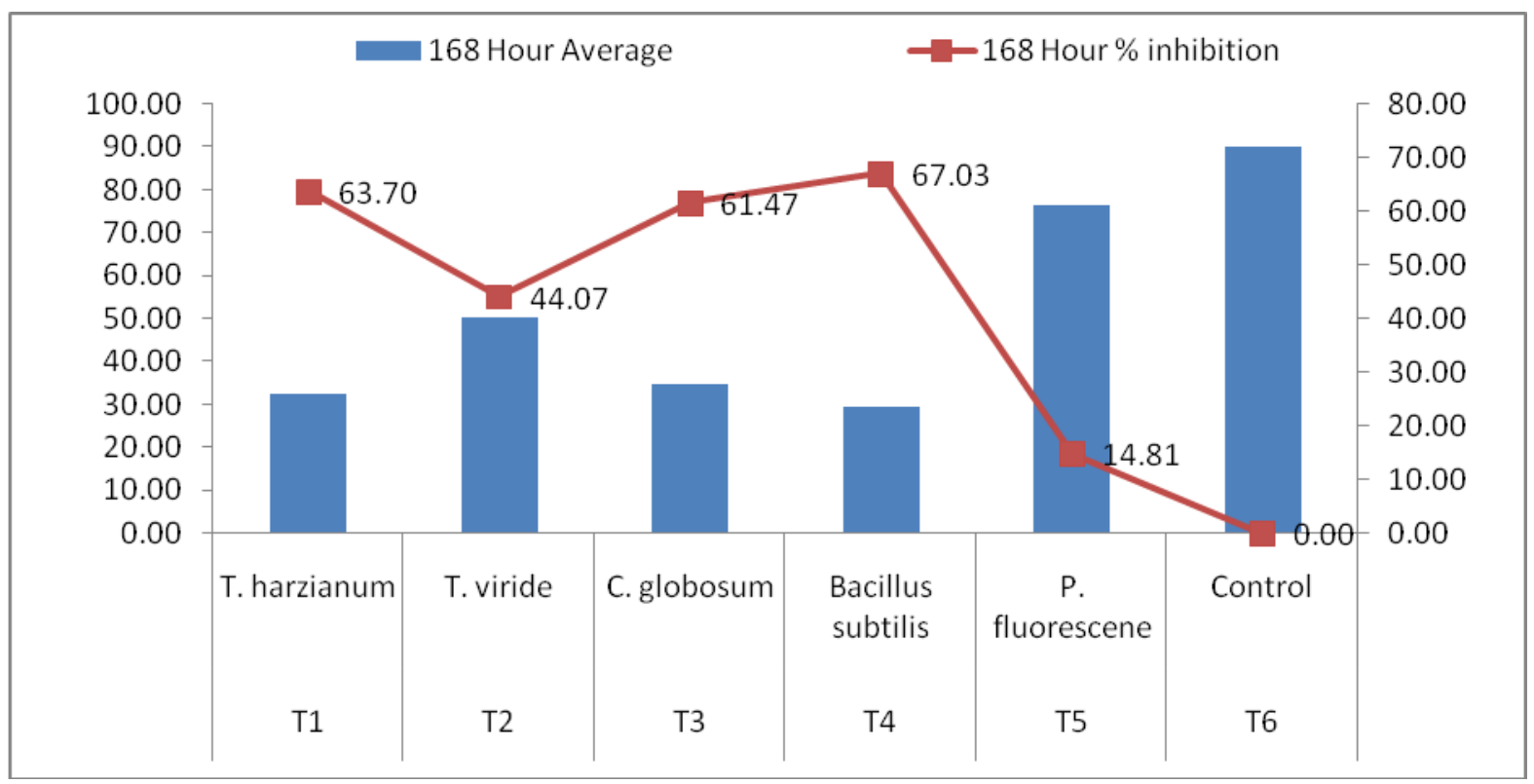


Plate.1 In vitro evaluation of different bioagents against $M$. phaseolina

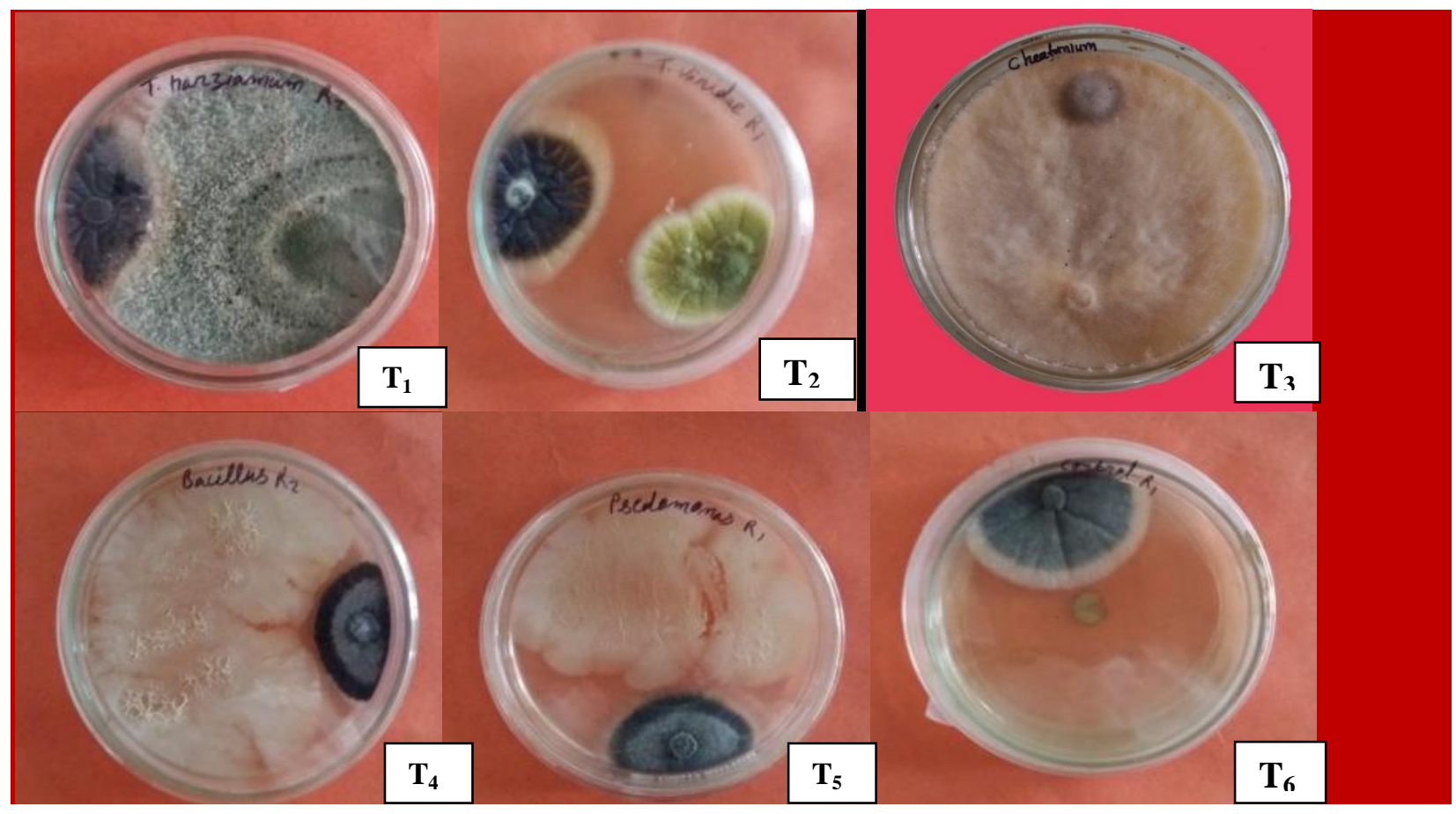

Figure.2 In vitro evaluation of different fungicides at 100ppm

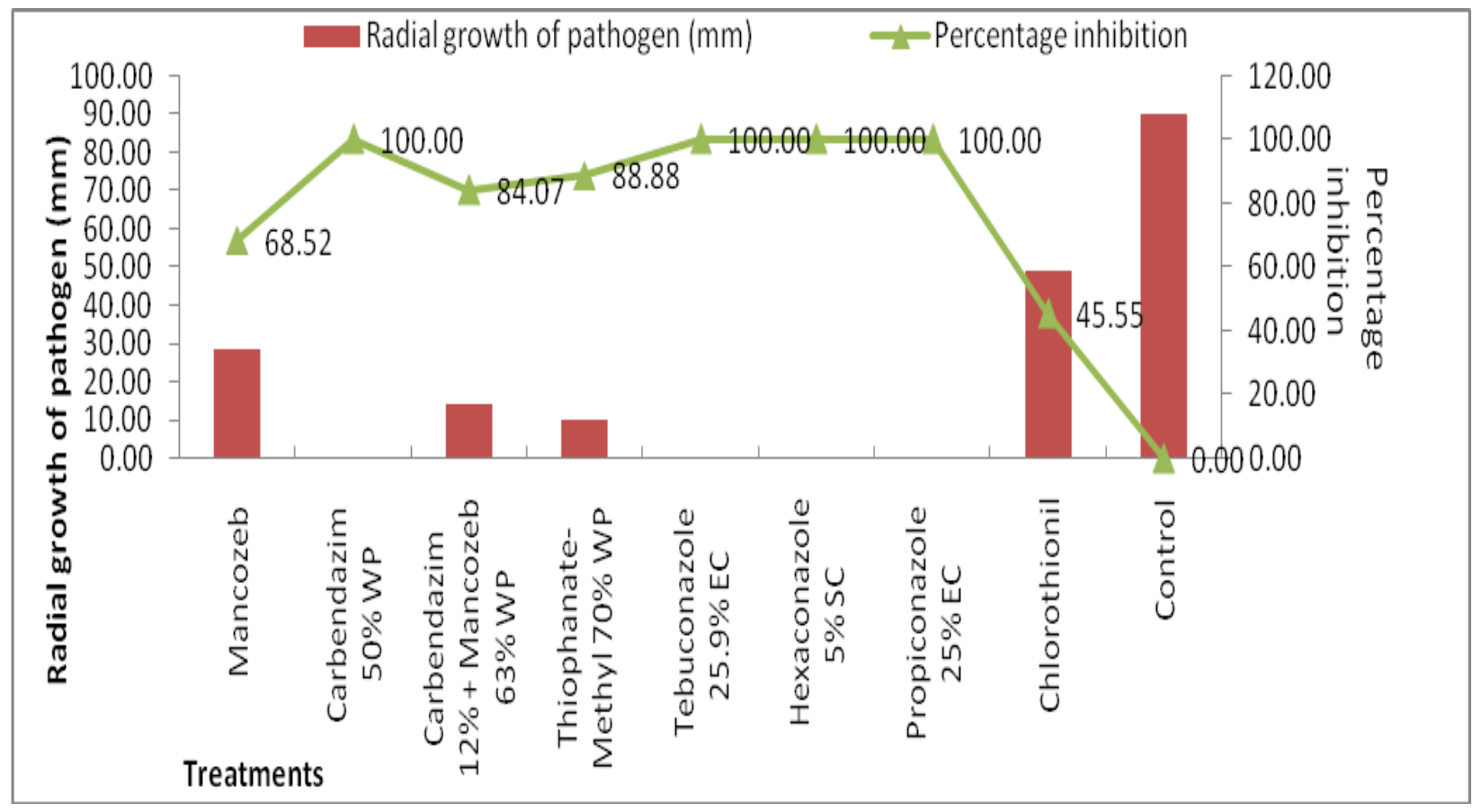


Plate.2 Evaluation of different fungicides (100ppm) against M. phaseolina in vitro

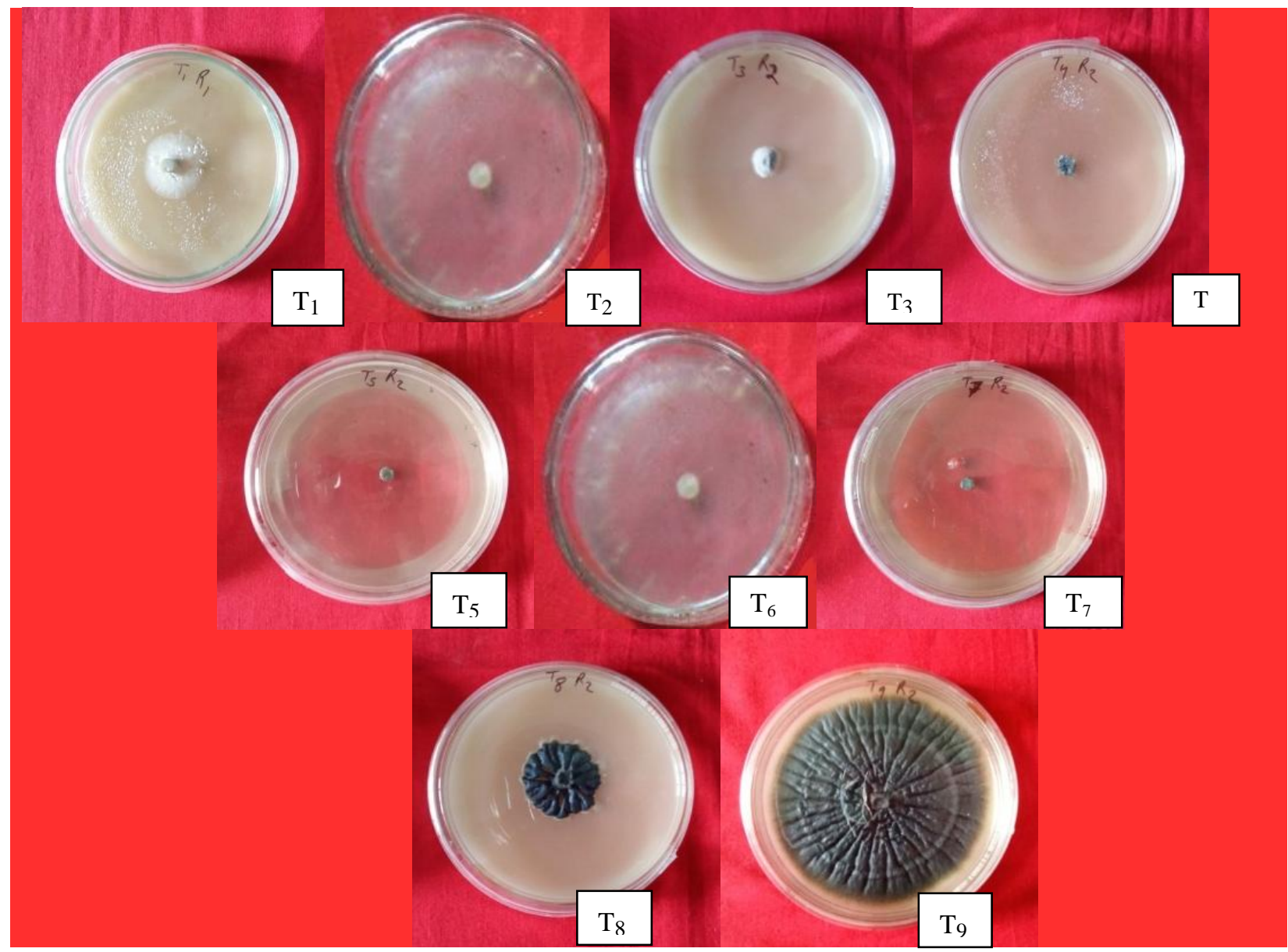

Figure.3 In vitro evaluation of different fungicides at 200ppm

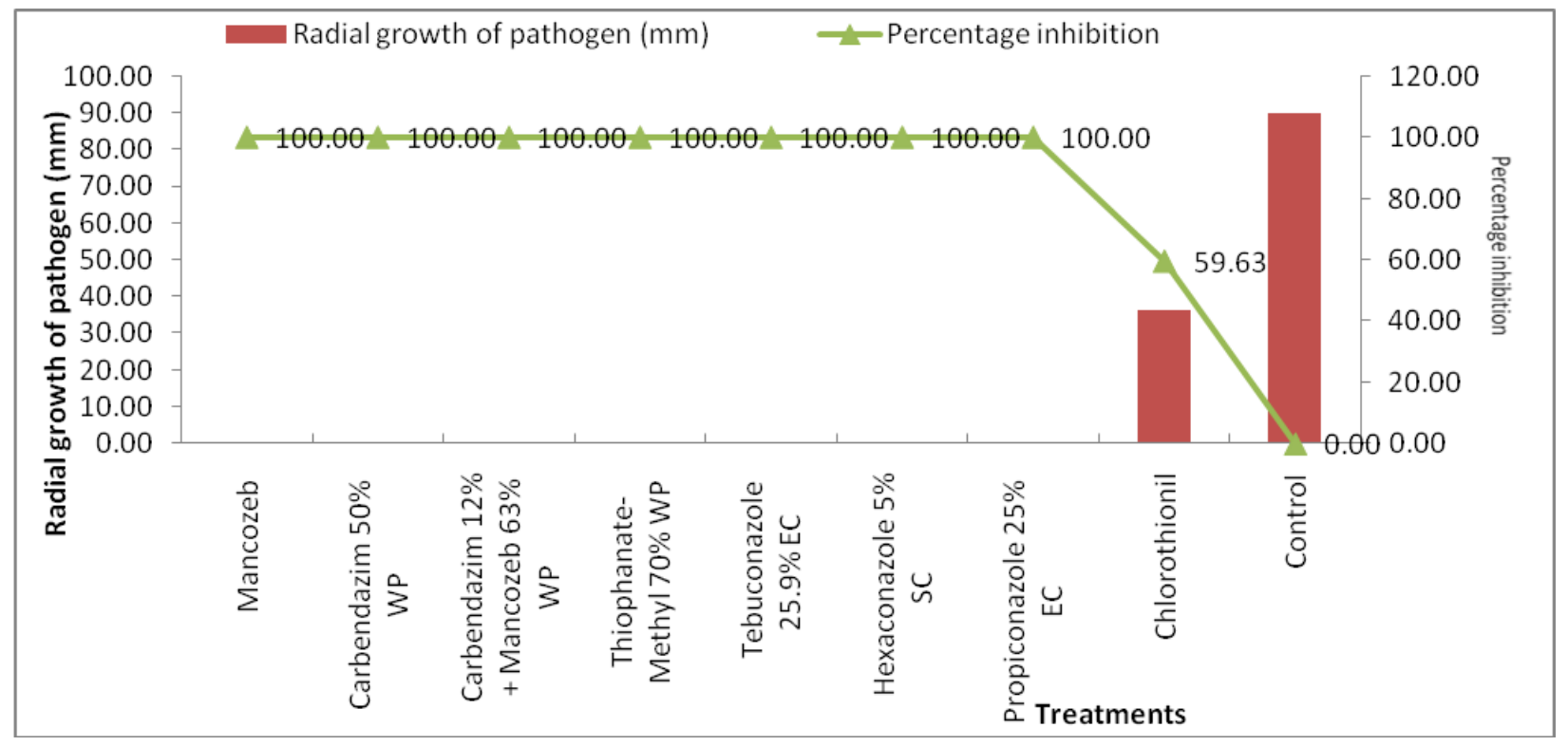


Plate.3 In vitro evaluation of different fungicides (200ppm) against M. phaseolina

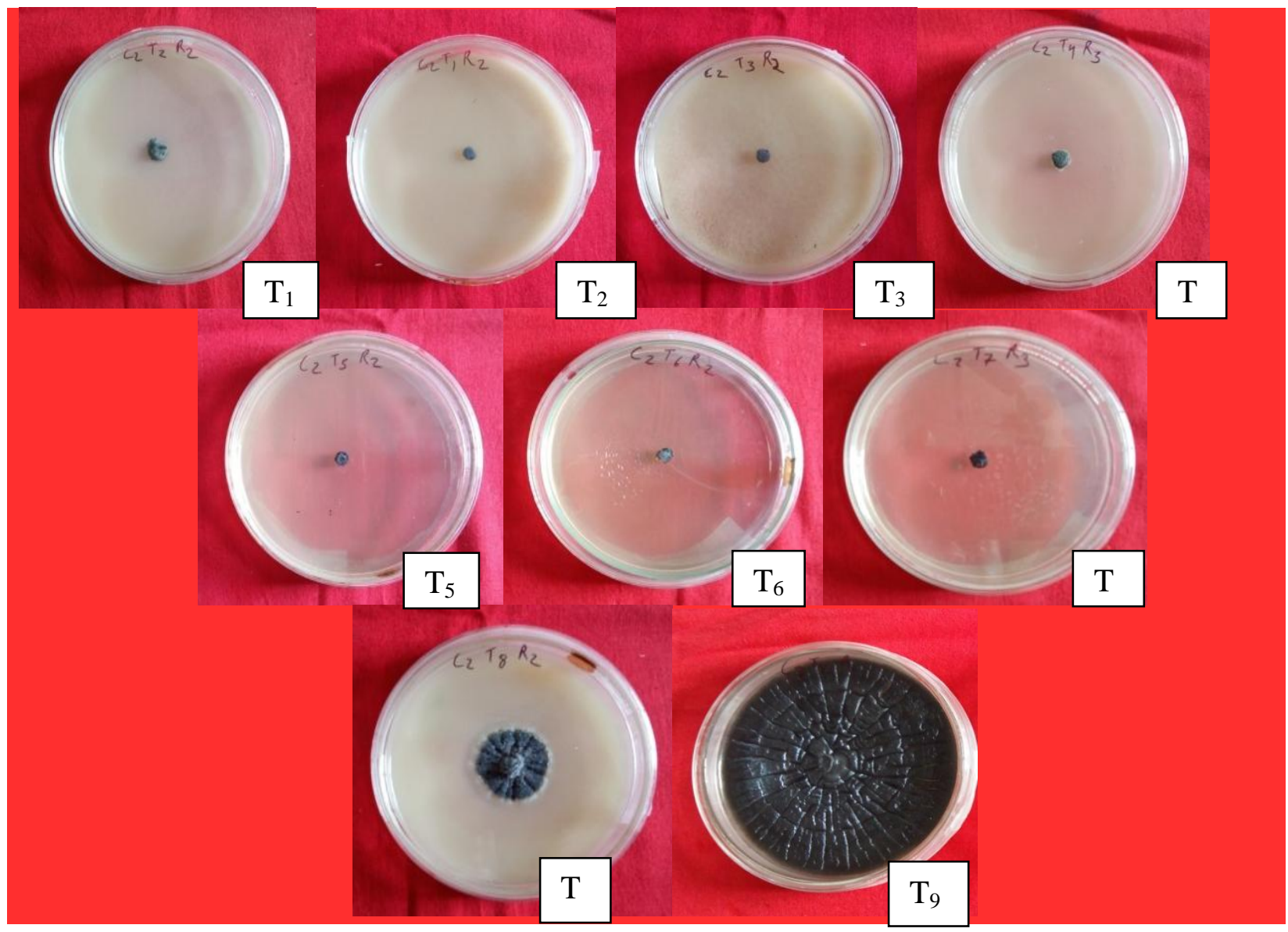

Figure.4 In vitro evaluation of different fungicides at 300ppm




Plate.4 In vitro evaluation of different fungicides (300ppm) against M. phaseolina

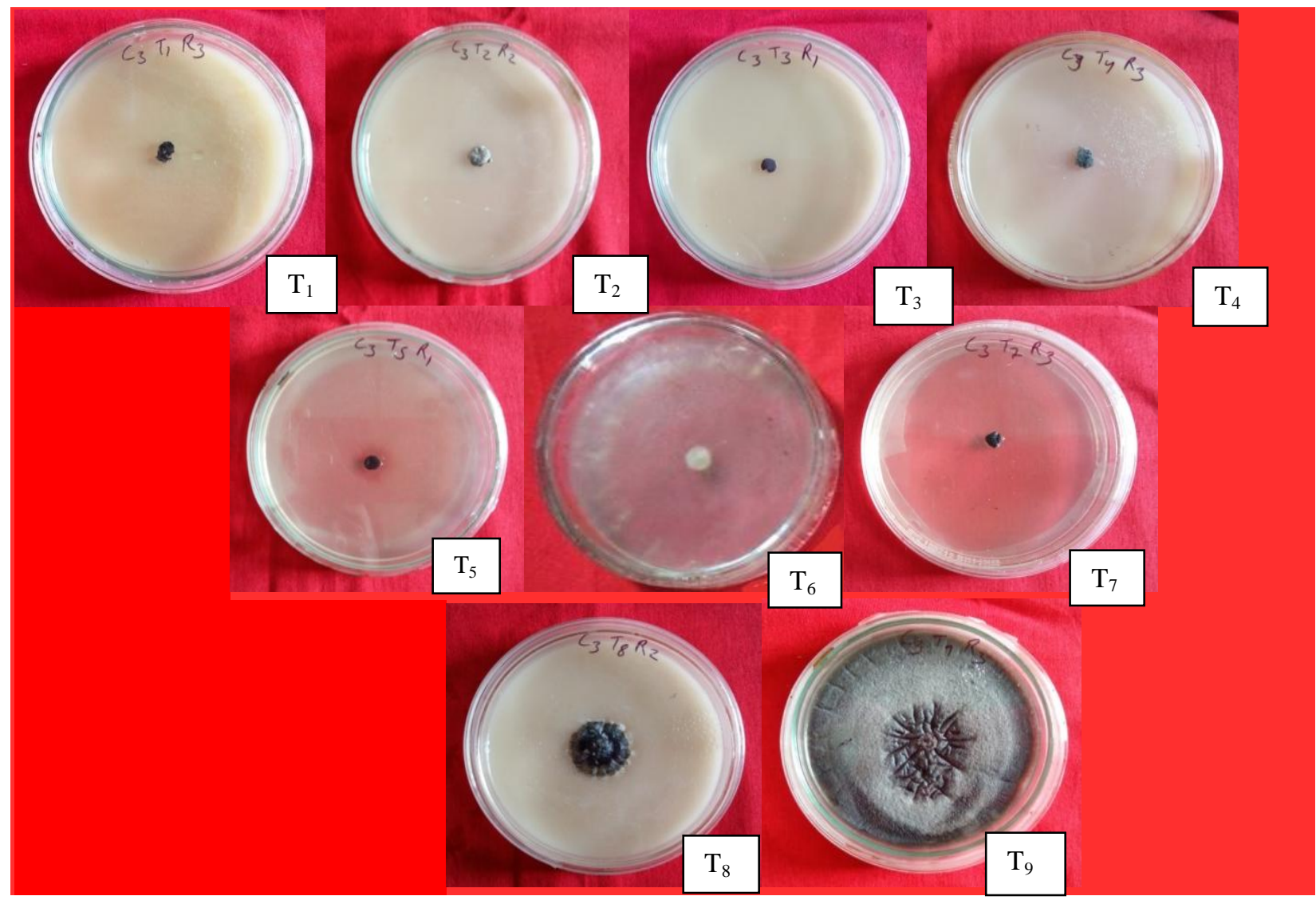

These findings were in close similarities with the earlier observations recoded by Sreedevi et al., (2011) who also had obtained in dual culture technique $T$. viride and $T$. harzianum reduced mycelial growth by $61.1 \%$ and $64.4 \%$, respectively. Alice et al, (1996) found that $T$. harzianum and $T$. viridae effective against $M$. phaseolina infecting Jasmine. Hasamedin (2008) observed the inhibition of root rot pathogen of egg plant by $T$. harzianum upto $18.20 \%$. Similarly, in addition, efficacy of other bio-agents i.e. T. virens, Pseudomonas flouresences and Bacillus spp against $M$. phaseolina is also documented (Lokesha and Benagi, 2007).

An experiment was conducted to determine the inhibitory effect of eight fungicides viz. Mancozeb 63\% WP, Carbendazim 50\% WP, Carbendazim 12\% + Mancozeb 63\% WP,
Thiophanate-Methyl 70\% WP, Tebuconazole $25.9 \%$ EC, Hexaconazole 5\% SC, Propiconazole 25\% EC and Chlorothalonil $75 \% \mathrm{WP}$ at different concentration viz.100, 200 and 300ppm by poisoned food technique, the radial growth of the pathogen were recorded at 24, 96 and $168 \mathrm{hrs}$ after incubation. Percent inhibition of the radial growth of the pathogen at different concentration of fungicides are presented in the Table-2,3,4,5 \& illustrated graphical in Figure-1,2,3,4 \& Plate-1,2,3,4.

Results showed that after 24 hrs of inoculation the complete inhibition of mycelial growth was found with all fungicides at all three 100, 200 and 300ppm conc., four fungicides Carbendazim, Tebuconazole, Hexaconazole and Propiconazole completely inhibited the 
mycelial growth of pathogen after 96 and $168 \mathrm{hrs}$ at $100 \mathrm{ppm}$ conc.. The fungicides Saaf $(84.07 \%)$ and Topsin-M (88.88\%) inhibited the pathogen growth significantly followed by Mancozeb (68.52\%) and least mycelial growth inhibition was recorded with Chlorothalonil (45.55\%) after $168 \mathrm{hrs}$ of inoculation.

The seven fungicides Mancozeb, Carbendazim, Saaf, Topsin-M, Tebuconazole, Hexaconazole and Propiconazole completely inhibited the mycelial growth of pathogen at 200 and $300 \mathrm{ppm}$ conc. The fungicide Chlorothalonil was found least effective to inhibit the growth of pathogen which inhibited $70.13 \%$ and $59.63 \%$ at $200 \mathrm{ppm}$ while $77.55 \%$ and $70.74 \%$ mycelial growth of pathogen at 300 ppm concentration after 96 and $168 \mathrm{hrs}$ of inoculation.

Concentrations also had significant inhibitory effects on the growth of the fungus. All the fungicides completely inhibited the mycelial growth of the fungus at 200 and 300ppm concentration except then chlorthionil which was least effective at both tested concentrations.

These findings were in close similarities with the earlier observations recorded by Choudhary et al., (2004) who also had obtained the effective inhibition in growth of Macrophomina phaseolina at higher concentration of Carbendazim, Antracol [propineb], Indofil M-45 [mancozeb + thiophanate-methyl] and Ridomil MZ [mancozeb + metalaxyl], applied at 300, 400, 500 and $1000 \mathrm{ppm}$, in inhibiting the mycelial growth of Macrophomina phaseolina). Similarly, Carbendazim inactivates tubulin function of pathogen necessary for their maintenance and growth (Butlers et al., 1995).

The present investigation it can be concluded that all the bioagents and fungicides which was inhibited the mycelial growth of the fungus (Macrophomina phaseolina) at all the concentration except then chlorthionil which was least effective at all tested concentrations.

\section{Acknowledgement}

The authors wish thank to HOD of Department of Plant Pathology, S.V.P. university of Agriculture and technology, Meerut- 250110 (U.P) for providing the research facilities.

\section{References}

Alice, D., E. G. Ebenezar and K. Siraprakasan (1996). Biocontrol of Macrophomina phaseolina causing root rot of jasmine. J. Ecobiol., 8: 17-20

Butlers, J. A., S. J. Kendall, I. E. Wheeler and D. W. Hollomon (1995). Tubulins: Lessons from Existing Products That Can Be Applied to Target New Antifungals. In: Antifungal Agents, Discovery and Mode of Actions. G. K. Dixon, L. G. Copping, D. W. Howwomon (Eds.), BIOS, Oxford .pp. 173- 191.

Choudhary, C. S., Singh, S. N. and Prasad, S. M. (2004). In vitro effectiveness of chemicals to control Macrophomina phaseolina (Tassi.) Goid, causing stem and root rot of sesame. J. Appl. Biology. 14 (1): 46-47.

Hesamedin Ramezani (2008). Biological Control of Root-Rot of Eggplant Caused by Macrophomina phaseolina. American-Eurasian J. Agric. \& Environ. Sci., 4 (2): 218-220.

Jukanti, A. K., Gaur, P.M., Gowda, C. L. L., and Chibbar, R. N. (2012). Nutritional quality and health benefits of chickpea (Cicer arietinum L.): a review. British Journal of Nutrition 108, S11-S26.

Lokesha, N. M and V. I. Benagi (2007). Biological Management of Pigeonpea Dry Root Rot Caused by 
Macrophomina phaseolina. Karnataka. J. Agric. Sci., 20 (1): 54 - 56.

Mihail, J. D. (1992). "Macrophomina”.Pp. 134-136. In: L.L. Singleton, J.D. and C.M Rush (Eds.) Methods for Research on soil borne phytopathogenic fungi. APS press, USA.

Nene, Y. L. and Thapliyal, P. N. (1979). Fungicides in plant disease control. Oxford \& IBH publishing Company, New Delhi (India): 507 pp.

Sreedevi, B., Charitha Devi, M. and Saigopal, D.V.R. (2011). Isolation and screening of effective Trichoderma spp. against the root rot pathogen Macrophomina phaseolina. Journal of Agricultural
Technology. 7(3): 623-635.

Vincent, T. M. (1927). Distartion of fungal hyphae in the presence of certain inhibitors, Nature., 159: 850-856.

Wyllie, T. D. (1988). Charcoal rot of soyabean-current status. Pages 106-113 In: I. D. Wyllie and K. H Scott, (Eds.). Soyabean Diseases of the North Central Region. The American Phytopathology Society, St. Paul. MN.

Yude, C., Kaiwei, H., Fuji, L. and Jie, Y. (1993). The potential and utilization prospects of kinds of wood fodder resources in Yunnan. Forestry Research 6, 346-350

\section{How to cite this article:}

Ranvijay, Prashant Mishra, Abhishek Kumar and Shashank Mishra. 2020. In vitro Efficacy of Bioagents and Fungicides on the Management of Dry Root Rot of Cluster Bean (Macrophomina phaseolina). Int.J.Curr.Microbiol.App.Sci. 9(09): 2022-2033. doi: https://doi.org/10.20546/ijcmas.2020.909.252 